\title{
MENINGKATKAN MINAT BELAJAR SOSIOLOGI MELALUI VIDEO NARASI CERITA KARYA SISWA DENGAN PLATFORM GOOGLE CLASSROOM
}

Oleh :

\author{
Ahmad Mustaufan ${ }^{1}$
}

\begin{abstract}
Abstrak
Penelitian ini bertujuan untuk mengetahui bagaimana model pembelajaran project based learning video narasi cerita dapat meningkatkan minat belajar siswa pada mata pelajaran sosiologi pada pokok bahasan masalah social dalam arus globalisasi di kelas XII IPS 2 SMA N 1 Mayong Tahun Ajaran 2020-2021. Jenis penelitian ini adalah penelitian tindakan kelas, dengan menggunakan model pembelajaran project based learning video narasi cerita. Pada setiap siklus peneliti melakukan pengamatan dan survey untuk mengetahui tingkat minat belajar siswa. Berdasarkan hasil observasi siswa mengalami perkembangan pengondisian pembelajaran. Berdasarkan hasil survey yang dilakukan penulis terhadap 32 siswa terdapat 36,7\% siswa memiliki minat belajar yang cukup tinggi pada tahap pra siklus. Kemudian pada siklus I memiliki nilai 54,9\% dan pada siklus II memiliki nilai $70,2 \%$. Dengan demikian dapat disimpulkan bahwa dengan menerapkan model pembelajaran model pembelajaran project based learning video narasi cerita dapat meningkatkan minat belajar siswa pada mata pelajaran sosiologi pokok bahasan masalah social dalam arus globalisasi kelas XII IPS 2 SMA N 1 Mayong Tahun Ajaran 2020-2021.
\end{abstract}

Kata Kunci: Minat Belajar, Video Narasi Cerita

\footnotetext{
${ }^{1}$ Guru Sosiologi di SMA Negeri 1 Mayong, Kabupaten Jepara, email : poutrileh@gmail.com
} 


\section{PENDAHULUAN}

Pendidikan adalah pembelajaran pengetahuan, keterampilan, dan kebiasaan sekelompok orang yang diturunkan dari satu generasi ke generasi berikutnya. Pendidikan menjadi satu media dalam perkembangan peradaban manusia, masyarakat dan negara. Masyarakat pada awalnya melaksanakan fungsi ini dalam keluarga. Seiring dengan perkembangan zaman, pendidikan akhirnya menjadi satu lembaga yang berdiri sendiri dan memiliki standar khusus dalam proses pendidikan. Namun, pendidikan yang bagus diperlukan minat belajar yang tinggi dari siswa maupun guru. Karena dari minat itu pendidikan dapat bergerak dengan ikhlas tanpa ada beban untuk menjalankannya.

Menurut Bloom (susanto:2012), minat adalah apa yang disebutnya sebagai subject-related affect, yang di dalamnya termasuk minat dan sikap terhadap materi pelajaran. Minat belajar (Ayu:2018) menjadi permasalahan dalam pendidikan Indonesia. Siswa seringkali merasa bosan dengan metode pembelajaran ceramah dan materi tekstual teoritis. Hal ini berdampak pada rendahnya peringkat pendidikan Indonesia. Sesuai dengan survey PISA (kemdikbud.go.id) yang menempatkan Indonesia pada peringkat ke 72 dari 77 negara pada tahun 2018. Ini adalah salah satu masalah yang harus diselesaikan dengan seefisien dan seefektivitas mungkin.

Globalisasi menjadi satu materi sosiologi kelas XII yang menjadi kelanjutan dari perubahan sosial. Globalisasi sendiri memiliki pengertian sebuah proses penduniaan dari beragam aspek budaya meliputi ide, benda, dan perilaku. Globalisasi masih sering menjadi materi teoritis bagi siswa. Sehingga, pemahaman siswa belum begitu kontekstual (kemdikbud.go.id). Perlu suatu inovasi dalam meningkatkan minat siswa dalam pemahaman kontekstual mengenai materi sosiologi, terutama globalisasi.

Salah satu upaya meningkatkan minat belajar siswa yaitu dengan menggunakan model pembelajaran yang kooperatif dan variatif. Model pembelajaran yang variatif hendaknya dapat meningkatkan minat belajar siswa. Model pembelajaran yang monoton akan memunculkan kebosanan pada siswa dan menurunkan minat belajar siswa. Video narasi singkat sering mereka unggah ke media sosial masing-masing. Video narasi sendiri merupakan sebuah perpaduan audio video yang diiringi dengan narasi tertentu yang memuat cerita, nasehat, hiburan ataupun himbauan tertentu. Video narasi ini dapat dimanfaatkan ke dalam model pembelajaran yang inovatif, berbasis ICT, HOTS dan kontekstual.

Video narasi ini diharapkan dapat menjadi media meningkatkan minat belajar siswa. Model pembelajaran project based learning dapat menjadi media penerapan video narasi cerita sebagai bahan pembelajaran siswa. Sehingga, kita perlu mencari tahu bagaimana model pembelajaran video 
narasi cerita dapat meningkatkan minat belajar siswa?.

Upaya meningkatkan minat belajar sering dengan beragam model pembelajaran pernah dilakukan oleh beberapa peneliti. Diantaranya ada Tioman Aritonang (2019) dalam jurnal daring (garuda.ristekbrin.go.id) yang berjudul peningkatan minat belajar dengan metode Tari Bambu yang menghasilkan peningkatan minat belajar dengan metode yang digunakan. Serta Deska Aji Pradipta (2017) juga dalam jurnal daring (garuda.ristekbrin.go.id) yang membahas tentang pengaruh minat belajar pada komunikasi matematis pemahaman konsep matematika yang membuktikan adanya pengaruh minat belajar terhadap keberhasilan prose belajar.

Berdasarkan uraian latar belakang di atas, penulis berupaya mengetahui bagaimana peningkatkan minat belajar sosiologi melalui video narasi karya siswa. Sehingga, model pembelajaran video narasi cerita karya siswa dapat diupayakan untuk meningkatkan minat belajar siswa dan dapat dijadikan referensi model pembelajaran bagi guru lainnya.

\section{METODE PENELITIAN}

Subjek penelitian dalam penelitian ini adalah seluruh siswa kelas XII IPS 2 SMA N 1 Mayong Kabupaten Jepara Tahun Ajaran 2020-2021. Objek penelitian ini adalah peningkatan minat belajar siswa pada mata pelajaran sosiologi pada pokok bahasan masalah social dalam arus globalisasi di kelas XII IPS 2 SMA N 1 Mayong Tahun Ajaran 2020-2021 yang berjumlah 32 orang.

Penelitian ini menggunakan penelitian tindakan kelas (PTK) yang bertujuan meningkatkan minat belajar siswa pada mata pelajaran sosiologi pokok bahasan masalah sosial dalam arus globalisasi. Sesuai dengan prinsip penelitian tindakan kelas, maka penelitian ini memiliki beberapa siklus tindakan. Setiap siklus dilaksanakan sesuai indikator keberhasilan tindakan.

Pada Tahap pra siklus siswa diberi kuesioner mengenai tingkatan minat belajar siswa dengan metode pembelajaran konvensional asinkronus dengan pemberian materi. Selain itu, peneliti juga melakukan pengamatan dalam pembelajaran konvensional menggunakan catatan observasi. Hasil kuesioner dan observasi yang dilakukan pada tahap pra siklus akan dijadikan pedoman dan acuan peningkatan minat belajar siswa.

Siklus I memiliki tindakan kepada objek penelitian dengan penerapan model pembelajaran project based learning video narasi cerita. Apabila hasil tindakan pada siklus I belum menunjukkan peningkatan minat belajar berdasarkan survey yang dilakukan, maka dilanjutkan dengan siklus berikutnya. Namun, jika sudah ada peningkatan minat belajar pada siklus I, siklus II akan tetap dilaksanakan sebagai penguatan bahwa model pembelajaran project based learning 
video narasi cerita dapat meingkatkan minat belajar siswa.

Pengumpulan data sesuai dengan tujuan penelitian ini diperoleh melalui kuesioner dan pengamatan yang dilakukan oleh guru sebagai peneliti dan dosen sebagai pembimbing penulisan penelitian tindakan kelas. Peneliti dan pembimbing saling berdiskusi mengenai perencanaan, pelaksanaan dan penulisan penelitian tindakan kelas yang dilakukan.

Uji keabsahan data digunakan
teknik triangulasi dengan cara memanfaatkan sumber lain sebagai pemeriksa keabsahan data. Teknik pemeriksaan keabsahan data yang memanfaatkan suatu yang lain diluar data itu untuk keperluan pengecekan atau sebagai pembanding terhadap data tersebut digunakan dalam penelitian ini (Sugiyono:2007). Sehingga, triangulasi sumber Data yang diperoleh dianalisis oleh peneliti sehingga menghasilkan suatu kesimpulan selanjutnya dimintakan kesepakatan (member check) dengan tiga sumber data dan triangulasi teknik peneliti melakukan diskusi lebih lanjut kepada sumber data yang bersangkutan untuk memastikan data mana yang dianggap benar (Sugiyono, 2007).

\section{HASIL}

A. Tahap Pra Siklus

Tahap pra siklus dalam penelitian ini menunjukkan pembelajaran daring asinkron konvensional. Guru sudah menggunakan google classroom dalam pembelajaran pra siklus.. Pembelajaran konvensional yang dilaksanakan adalah guru memberikan sambutan, motivasi, dan semangat melalui google classroom. Guru juga melampirkan beragam link materi, video dan beberapa penugasan dalam pembelajaran pra siklus di kelas XII IPS 2. Sehingga, interaksi terjadi tidak langsung dan kurang intensif antara guru dan siswa.

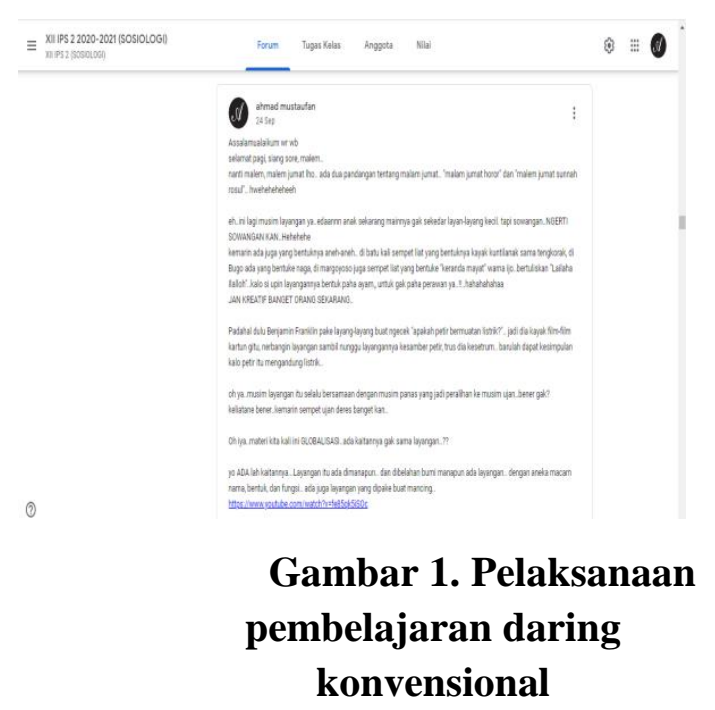

Tahap pra siklus menunjukkan suasana pembelajaran daring yang monoton. Jumlah keikutsertaan siswa dalam pembelajaran tidak begitu tinggi. Hanya 17 siswa (56\%) dari 32 siswa berperan aktif dalam pembelajaran asinkron. Padahal pembelajaran sudah dilaksanakan secara fleksibel, tanpa ada tekanan dalam pelaksanaan pembelajaran. Siswa tidak begitu tertarik dengan materi yang mayorittas berisi tulisan dan tidak menuntut kreativitas siswa dalam mengerjakan tugas.

Tujuan utama dilaksanakan pembelajaran daring konvensional adalah 
menjangkau keseluruhan siswa yang memiliki keterbatasan. Siswa lebih fleksibel dalam pembelajaran asinkron.Namun, hal ini berdampak pada minat belajar peserta didik yang kecil.

Data yang didapat dari google form dalam angket pra siklus menunjukkan kecilnya minat peserta didik dalam pembelajaran daring konvensional.

Pembelajaran daring seperti sebelum-sebelumnya secara konvensional sangat

menyenangkan

32 targgapan

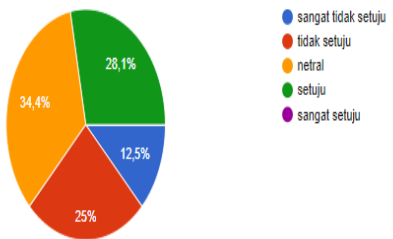

Gambar 2. Hasil tabel pertanyaan kuesioner google form tentang kesenangan siswa

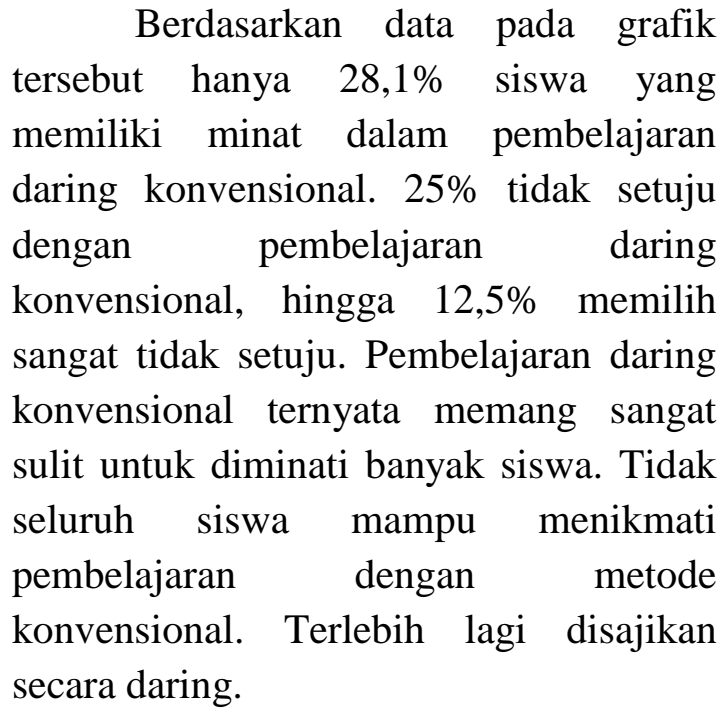

Saya tertarik dan semangat dalam mengeriakan tugas dalam pembelajaran daring konvensional

32 tanggaanan

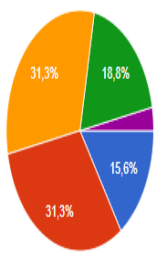

sangat idak setui

Tidak Set Tu

Setuju

Sangat Settui

\section{Gambar 3. Tabel pertanyaan kuesioner melalui google form}

Ketertarikan dan semangat dalam mengerjakan tugas oleh siswa juga cenderung kecil. Hanya $18,8 \%$ siswa mengatakan setuju dengan ketertarikan pembelajaran daring konvensional. Kejenuhan pembelajaran daring selama masa pandemi menghasilkan minat belajar rendah pada pembelajaran pra siklus.

Berdasarkan kuesioner pra siklus yang sudah disebar oleh peneliti menunjukkan bahwa $36,7 \%$ siswa memiliki minat pada pembelajaran daring konvensional. 20,3\% menunjukkan minat yang netral, dan $43 \%$ tidak memiliki minat dalam pembelajaran daring konvensional. Ini menunjukkan bahwa minat pembelajaran pra siklus perlu ditingkatkan dalam siklus I.

\section{B. Siklus I}

Siklus I menjadi tindakan awal pada PTK di kelas XII IPS 2 SMA N 1 Mayong tahun ajaran 2020-2021. Siklus I dilaksanakan satu kali pertemuan secara sinkronus. Siklus I menggunakan metode pembelajaran project based learning. Pada intinya, siswa diminta untuk membuat video cerita narasi yang mengandung 
materi yang sedang dikaji. Materi yang menjadi kajian dalam siklus I adalah faktor pendorong globalisasi di masyarakat.

Siklus I diawali dengan pemberitahuan melalui google classroom bahwa akan diadakan pertemuan sinkronus melalui zoom meeting. Siswa diminta mempersiapkan diri dan gadget mereka supaya bisa mengikutinya. Siswa yang merasa keberatan atau tidak bisa mengikuti diperkenankan untuk menyampaikannya langsung kepada peneliti. Pada akhirnya beberapa siswa menginformasikan kendala teknis untuk mengikuti zoom meeting. Zoom meeting berisi pemaparan materi faktor pendorong globalisasi dan proyek pembuatan video cerita narasi.

Setelah menunggu sekitar lima menit di zoom meeting, akhirnya $40 \%$ siswa berhasil terkoneksi. Pembelajaran dimulai dengan absensi, motivasi dan doa. Pemaparan materi dimulai dengan menyajikan stimulus berupa video awal lahirnya mobil hingga perkiraan mobil di masa depan yang juga menunjukkan beragam stimulus faktor pendorong globalisasi. Diskusi juga dilaksanakan dalam zoom meeting, untuk mengukur pemahaman materi dasar yang telah disampaikan. Selanjutnya penjabaran materi faktor pendorong globalisasi. Siswa mendengarkan dan tidak mengganggu pemaparan materi.

Penugasan video narasi cerita dikerjakan secara berkelompok. Sebanyak 32 siswa kelas XII IPS 2 dibagi menjadi enam kelompok. Empat kelompok terdiri dari lima siswa, dua kelompok terdiri dari enam siswa.
Setelah siswa memahami penugasan video narasi cerita yang disampaikan. Lembar Kerja Peserta Didik (LKPD) dibagikan melalui google classroom. LKPD tersebut menjadi media pengumpulan tautan video secara daring melalui situs jejaring video youtube. Hasil observasi menunjukkan peningkatan minat belajar. Karena dalam waktu dua hari, sudah terkumpul lima video narasi melalui google classroom. Tersisa satu kelompok saja yang belum mengumpulkan. Berbeda dengan tahap prasiklus yang menunjukkan minat yang kecil dalam pembelajaran.

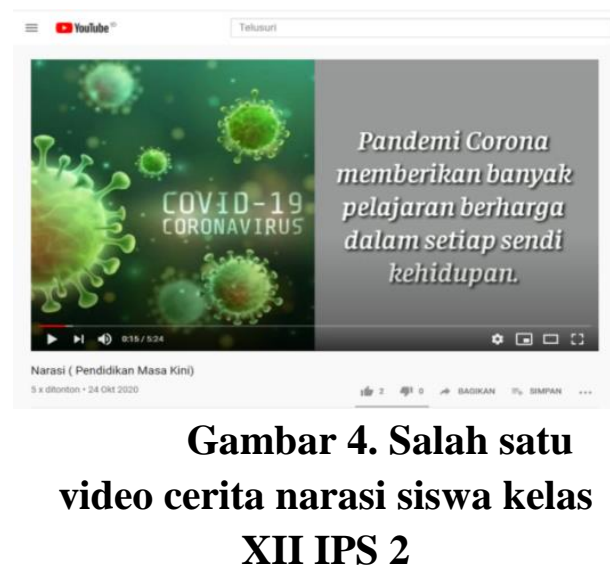

Pada hasil kuesioner yang dibagikan melalui google classroom dengan memanfaatkan aplikasi google form juga menunjukkan peningkatan minat belajar siswa. Kepercayaan diri siswa meningkat dalam pengerjaan video narasi cerita. Terlihat dari hasil kuesioner menunjukkan siswa merasa meningkat kreativitasnya ketika setelah mengerjakan pembelajaran siklus II. Lebih dari separuh siswa memilih setuju atas peningkatan kreativitas siswa dalam pembelajaran. Sedangkan yang memilih untuk netral dan tidak setuju sejumlah 23,1\%. Ini cukup 
menunjukkan peningkatan minat belajar siswa. Karena kepercayaan diri dalam belajar merupakan satu faktor penunjang utama dalam proses belajar.

Tidak hanya kepercayaan diri yang meningkat. Pemahaman kontekstual materi faktor pendorong globalisasi juga terjadi peningkatan. Hal ini ditunjukkan melalui isi video yang dapat mencontohkan dengan baik materi tersebut. Juga melalui kuesioner yang telah dibagikan secara daring.

Sebanyak 53,8\% siswa menyatakan diri lebih memahami materi melalui pembelajaran siklus I. Berbeda dengan pra siklus yang hanya $11 \%$ saja siswa yang menyatakan pemahaman materi pembelajaran.

Hasil akhir kuesioner juga menunjukkan nilai $54,9 \%$ siswa memiliki minat belajar dalam pembelajaran siklus I. 30,4\% menunjukkan minat netral dan $14,7 \%$ tidak menunjukkan minat belajar yang tinggi. Jika dibandingkan dengan pra siklus yang hanya menunjukkan $36,7 \%$, menunjukkan bahwa dalam pembelajaran siklus I mengalami peningkatan minat belajar pada siswa kelas XII IPS 2 SMA N 1 Mayong tahun ajaran 2020-2021.

\section{Siklus II}

Siklus II sama seperti siklus I, dimana peneliti masih menggunakan metode project based learning. Perbedaannya peneliti menggunakan materi gejala-gejala globalisasi dalam masyarakat.

Zoom meeting yang dilakukan peneliti dalam penjabaran materi gejala globalisasi berlangsung pada selasa, 3
November 2020. Pada kegiatan zoom meeting, siswa antusias mengikuti pembelajaran. Kegiatan pengondisian dalam pembelajaran jauh lebih baik jika dibanding dengan siklus I. Siswa bisa mengatur tombol mute pada aplikasi. Jikalau kesulitan, maka peneliti sebagai host langsung mematikan mic milik siswa. Hal ini dilakukan dalam pelaksanaan pengondisian pembelajaran sinkronus. Sehingga siswa dapat fokus pada materi yang disampaikan.

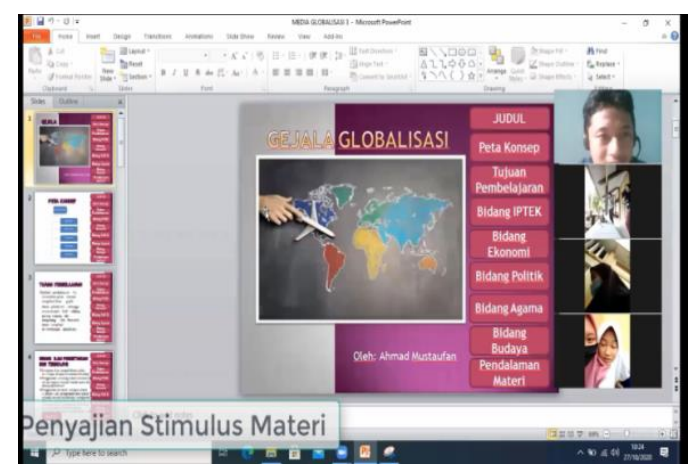

\section{Gambar 5. Zoom meeting} siklus II

Zoom meeting juga menyajikan diskusi megenai materi gejala-gejala globalisasi. Diskusi berisi tanya jawab mengenai gejala globalisasi yang terjadi disekitar masyarakat. Gejala globalisasi mengenai teknologi, fashion, musik, dan lain sebagainya menjadi pembahasan dalam diskusi. Beberapa siswa juga antusias turut memberikan argumen dalam diskusi.

Zoom berikutnya berisi penjabaran pembuatan video narasi yang mirip dengan siklus I. Siswa diminta 
membuat video narasi cerita mengenai gejala-gejala globalisasi. Pengelompokan siswa juga menggunakan pengelompokan yang sama. Karena mereka masih aktif dalam praktik tari, sehingga intensitas pertemuan mereka cukup banyak dalam pengerjaan video cerita narasi yang juga akan diupload di youtube. Pengelompokan yang sama dipilih peneliti karena lebih efisien dan efektif di masa pandemi yang menghendaki pengurangan kegiatan kerumunan.

Kuesioner disebar dalam proses pembuatan video cerita narasi. Seperti di siklus I, kuesioner disebar secara daring menggunakan platform google form, sehingga lebih efektif dan efisien. Sebanyak 32 siswa sudah menanggapi kuesioner yang telah disebarkan. Sehingga $100 \%$ anggota kelas XII IPS 2 sudah mengisi kuesioner yang telah disebar.



\section{Gambar 6. Hasil salah satu pertanyaan dalam kuesioner.}

Gambar tabel lingkaran di atas juga menunjukkan peningkatan pada rasa kreativitas siswa dalam pembelajaran video narasi cerita. $47,1 \%$ siswa merasa lebih kreatif dalam kuesioner siklus II. Siswa juga menjadi banyak belajar. Pembelajaran menggunakan kreativitas video narasi cerita memang sedikit menuntut siswa menggunakan aplikasi editing video. Sehingga siswa harus mempelajari aplikasi editing video pada smartphone masing-masing. $61,8 \%$ siswa memilih setuju dalam pemahaman aplikasi editing video dalam smartphone. $8,8 \%$ siswa juga memilih sangat setuju tentang penggunaan aplikasi editing video.

Hasil akhir dari kuesioner siklus II yang disebar oleh peneliti menggunakan platform google classroom juga menunjukkan peningkatan jika dibandingkan dengan siklus I. Prosentase akhir yang didapat adalah $70,2 \%$ siswa masih memiliki minat dalam pembelajaran menggunakan kreasi video narasi cerita karena siswa tersebut memberi jawaban setuju dan sangat setuju pada tiap pertanyaan di kuesioner. $23,4 \%$ siswa menunjukkan minat belajar netral dan $6,4 \%$ menunjukkan minat belajar yang masih rendah.

\section{DISKUSI}

Pembelajaran sinkronus yang dilakukan pada kelas XII IPS 2 menghasilkan perkembangan. Siswa yang awalnya masih kaget dengan sistem pembelajaran sinkronus pada siklus I, perlahan mulai terbiasa pada siklus II. Pengondisian siswa pada siklus II cenderung lebih mudah jika dibanding siklus I. Siswa juga lebih menguasai setiap tombol pada aplikasi pembelajaran sinkronus.

Pembelajaran sosiologi materi masalah sosial dalam globalisasi dengan 
metode video narasi cerita yang terkait dengan materi dapat meningkatkan minat belajar siswa. Hal ini dapat dilihat dari peningkatan prosentase minat kuesioner yang dibagikan peneliti. Tentu dengan perlakuan yang sama dengan peneliti lakukan dalam penelitian ini. Seperti pemanfaatan zoom dalam pembelajaran sinkronus dan google classroom dalam pembelajaran asinkron.

Berdasarkan hasil penelitian tindakan kelas yang dilakukan pada kelas XII IPS 2 SMA N 1 Mayong tahun ajaran 2020-2021 menunjukkan bahwa, pada masa pra siklus minat belajar siswa hanya sekitar 36,7\%. Hal ini terbukti hanya $36,7 \%$ dari 32 siswa yang memilih jawaban setuju dan sangat setuju pada kuesioner yang dibagi. Peningkatan sudah terlihat pada siklus I. Minat siswa pada pembelajaran dengan kreasi video narasi meningkat menjadi 54,9\%. Begitu juga dengan siklus II, peningkatan meningkat menjadi 70,2\% siswa memilih jawaban setuju dan sangat setuju. Ahmad Susanto (2013: 66) yang menyatakan bahwa proses belajar akan lancar kalau disertai dengan minat. Hal ini selaras dengan hasil penelitian ini. Peningkatan minat belajar pada kelas XII IPS 2 SMA N 1 Mayong dapat melancarkan proses pembelajaran yang dilakukan

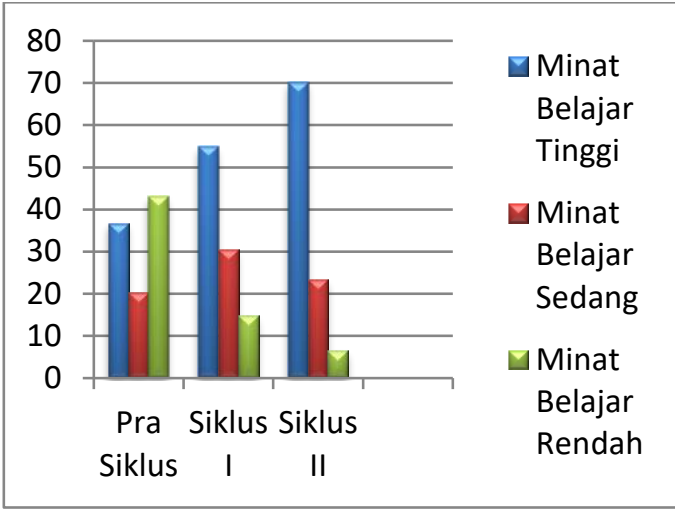

\section{Gambar 7. Tabel perkembangan tiap siklus}

Berdasarkan tabel tersebut dapat disimpulkan peningkatan minat belajar siswa. Sehingga dapat dibuktikan bahwa dengan model pembelajaran project based learning video narasi cerita dapat meningkatkan minat belajar siswa kelas XII IPS 2 SMA N 1 Mayong Kabupaten Jepara Tahun Ajaran 2020-2021.

\section{KESIMPULAN}

Hasil penelitian tindakan kelas terkait "Meningkatkan Minat Belajar Sosiologi Melalui Video Narasi Cerita Karya Siswa" yang dilakukan pada kelas XII IPS 2 SMA N 1 Mayong Tahun Ajaran 2020-2021 adalah Penerapan pembelajaran dengan kreasi video narasi cerita terkait materi sosiologi berhasil meningkatkan minat siswa dalam belajar. Hasil angket pada siklus 1 berhasil meningkatkan minat siswa menjadi 
$54,9 \%$. Begitu juga dengan siklus juga yang meningkat menjadi $70,2 \%$.

Peningkatan minat tidak hanya terlihat pada hasil akhir kuesioner yang dibagikan oleh peneliti. Melainkan juga melalui observasi yang menunjukkan ketertiban siswa dalam pengumpulan tugas secara daring. Pengondisian siswa pada pembelajaran sinkronus pada siklus 2 cenderung lebih kondusif dan aktif. Hal ini terlihat dari kemampuan siswa mengoperasikan aplikasi pembelajaran sinkronus.

\section{Daftar Pustaka}

Ainurrahman. (2009). Belajar dan Pembelajaran. Bandung: Alfabeta.

Aji Pradipta, Deska. (2017). Pengaruh Minat Belajar dan Komunikasi Matematis terhadap Pemahaman Konsep Matematika. Jurnal Online Garuda Ristekbrin

Aritonang, Tioman. (2019). Meningkatkan Minat Belajar PKn Menggunakan Model Pembelajaran Tari Bambu. Jurnal Online Garuda Ristekbrin

Depdiknas. (2003). Undang-undang RI No.20 tahun 2003 tentang sistem pendidikan nasional.

Diemas P.P Dan Rina Harimurti. (2017). Pengaruh Penerapan Tools Google Clasroom Pada Model Pembelajaran Project Based Learning Terhadap Hasil Belajar Siswa. Jurnal IT-Edu 2(1), 59-67.

Hardiyana, Andri. (2015). Implementasi Google Classroom sebagai Alternatif dalam Meningkatkan Mutu Pembelajaran di Sekolah. Karya Tulis Ilmiah, Cirebon : SMA Negeri 1 Losari.

Prasiska Dewi, Ayu. (2018). Upaya Meningkatkan Minat Belajar Siswa Dengan Menggunakan Model Snowball Throwing Pada Mata Pelajaran Pkn. Skripsi:Unisnu Sumut

Sugiyono. 2007. Metode Penelitian Kuantitatif Kualitatif dan $R \& D$. Bandung: Elfabeta.

Susanto, Ahmad. (2013). Teori Belajar \& Pembelajaran di Sekolah Dasar. Jakarta: Kencana.

Susanto. (2012). Teori Belajar Pembelajaran di Sekolah Dasar. Jakarta: Pranada Media Group 